\title{
Tuberculin Skin Testing versus Interferon-Gamma Release Assay among Users of a Public Health Unit in Northeast Portugal
}

\author{
Andrea Luísa Fernandes Afonso ${ }^{a, b} \quad$ Bruno Miguel Morais Pires ${ }^{b}$ \\ Cristina Martins Teixeira ${ }^{a, c}$ António José Nogueira ${ }^{a} d$ \\ ${ }^{a}$ School of Health Sciences, Polytechnic Institute of Bragança, Bragança, Portugal; ${ }^{b}$ Local Health Unit, Public Health \\ Laboratory of Bragança, Bragança, Portugal; ' EPI Unit - Instituto de Saúde Pública, Universidade do Porto, Porto, \\ Portugal; ${ }^{d}$ Centro de Investigação de Montanha (CIMO), Instituto Politécnico de Bragança, Bragança, Portugal
}

\section{Keywords}

Tuberculosis - Latent tuberculosis infection - Tuberculin skin test · Interferon-gamma release assay

\begin{abstract}
The screening of groups with a high risk for developing tuberculosis (TB) is a priority in order to control this disease. Since there is no gold standard for the diagnosis of latent TB infection (LTBI), both the tuberculin skin test (TST) and the interferon-gamma release assays (IGRA) have been used for this purpose. The aim of this study was to determine the proportion of LTBI by using the TST and the IGRA tests, and to assess the risk factors related with discordant results between tests across several risk groups advised for screening in Northeast Portugal. Data were collected from the database of patients with suspected LTBI and advised for the screening in a public health unit (January 2014 to December 2015). The proportion of LTBI was computed using both tests. Logistic regression models assessed risk factors for a positive test and for discordant results between tests. The adjusted odds ratio (OR) and respective $95 \%$ confidence in-
\end{abstract}

terval $(95 \% \mathrm{Cl})$ were obtained. Out of 367 patients included in the analysis, $79.8 \%$ had a positive TST and $46.0 \%$ of them had a positive IGRA. In comparison with contacts of active TB cases, healthcare workers and inmates presented higher odds of TST positivity (OR 4.38, 95\% CI 1.59-12.09 and OR $4.74,95 \% \mathrm{Cl} 1.45-15.49$, respectively), but immunocompromised people presented lower odds of TST positivity (OR $0.14 ; 95 \% \mathrm{Cl} 0.06-0.31$ ). Instead, healthcare workers (OR 0.44, $95 \% \mathrm{Cl}$ 0.24-0.80) and immunocompromised people (OR $0.24,95 \% \mathrm{Cl} 0.10-0.56)$ presented lower odds of a positive IGRA. There were $42.0 \%$ concordant positive results, $16.1 \%$ concordant negative results, and $41.9 \%$ discordant results, with healthcare workers presenting higher odds of discordant results (OR 3.34, 95\% Cl 1.84-6.05). The proportion of LTBI estimated by TST and IGRA among people advised for screening in our setting is high, highlighting the need of preventive strategies. Among healthcare workers, TST results should be read with caution as the higher proportion of discordant results with a positive TST suggests the impact of the booster reaction in this group.

(C) 2021 The Author(s). Published by S. Karger AG, Basel on behalf of NOVA National School of Public Health (c) 2021 The Author(s). Published by S. Karger AG, Basel on behalf of NOVA National School of Public Health

This is an Open Access article licensed under the Creative Commons Attribution-NonCommercial-4.0 International License (CC BY-NC) (http://www.karger.com/Services/OpenAccessLicense), applicable to the online version of the article only. Usage and distribution for commercial purposes requires written permission.
Cristina Martins Teixeira

Instituto de Saúde Pública, Universidade do Porto

Rua das Taipas 135

PT- 4050-600 Porto (Portugal)

cristina.teixeira@ipb.pt 
Teste Intradérmico da Tuberculina versus Teste de Deteção de Interferão-Gama numa Unidade de Saúde no Nordeste de Portugal

\section{Palavras Chave}

Tuberculose · Infeção Tuberculosa Latente · Teste Intradérmico à Tuberculina - Teste de Deteção de Interferão-Gama

\section{Resumo}

O rastreio de grupos de risco para o desenvolvimento de tuberculose (TB) é uma prioridade para o controlo da doença. Uma vez que não existe um "gold-standard" para o diagnóstico de infeção latente (ITBL), o teste intradérmico da tuberculina (TST) e o teste de deteção de interferão-gama (IGRA) têm sido usados com esse propósito. O objetivo deste estudo foi determinar a proporção de ILTB através do TST e do teste IGRA e avaliar os fatores associados à discordância de resultados entre testes, considerando vários grupos de risco aconselhados para rastreio no Nordeste de Portugal. Os dados foram obtidos da base de dados de utentes de uma unidade local de saúde com suspeita de ILTB e orientados para rastreio (janeiro de 2014 a dezembro de 2015). Foi obtida a proporção de ILTB usando ambos os testes. Os modelos de regressão logística avaliaram os fatores de risco para um teste positivo e para resultados discordantes entre os testes. Obtiveram-se as estimativas de odds ratio (OR) e o respetivo intervalo de confiança de $95 \%$ (IC95\%). Dos 367 pacientes incluídos na análise, 79,8\% tiveram um TST positivo e 46,0\% deles tiveram um IGRA positivo. Em comparação com contatos de casos de TB ativa, o risco de TST positivo foi maior em profissionais de saúde e presidiários (OR = 4.38; 95\% Cl: 1.59-12.09 e OR = 4.74 95\% Cl: 1.45-15.49, respetivamente) e menor em imunocomprometidos $(\mathrm{OR}=0.14 ; 95 \% \mathrm{Cl}$ : 0.06-0.31). Por outro lado, os profissionais de saúde (OR $=0.44 ; 95 \% \mathrm{Cl}$ : 0.24-0.80) e imunocomprometidos (OR = 0.24; IC95\%: 0.10-0.56) apresentaram menor risco de IGRA positivo. Houve $42.0 \%$ de resultados positivos concordantes, $16.1 \%$ de negativos concordantes e $41.9 \%$ de discordantes, com os profissionais de saúde a apresentarem maior risco de resultados discordantes (OR = 3.34; 95\% Cl: 1.84-6.05). A proporção de ILTB estimada pelo TST e IGRA nestes utentes aconselhados a fazer rastreio revelou-se alta, evidenciando a necessidade de estratégias preventivas. Entre os profissionais de saúde, os resultados do TST devem ser lidos com cautela, pois a maior proporção de resultados discordantes com um TST positivo sugere o impacto do efeito booster neste grupo.

๑ 2021 The Author(s) Published by S. Karger AG, Basel

\section{Introduction}

Tuberculosis (TB) results from Mycobacterium tuberculosis infection, which infects almost a quarter of the world's population and remains an important cause of ill health and mortality worldwide [1]. Over $90 \%$ of infected individuals remain asymptomatic and are not infectious due to the persistent immune response to M. tuberculosis that persists within the human host as latent TB infection (LTBI). People with LTBI are at risk of developing active TB disease and becoming infectious during their lifetime, leading to death if left untreated [2]. Specific groups of people have a high risk of developing TB, including contacts of TB cases [3-5], HIV-positive people [6], healthcare workers $(\mathrm{HCW})[6,7]$, immigrants from countries with a high TB burden [3], immunocompromised patients [6], prisoners, homeless people, and illicit drug users [8].

The prophylaxis of individuals with LTBI is a strategy to control active $\mathrm{TB}$, but there are no accurate methods to identify these individuals [1]. Diagnosis of LTBI relies on the measurement of host immune responses to M. tuberculosis antigens which are based on a specific immune response against the bacillus, by using the tuberculin skin test (TST) or interferon-gamma (IFN- $\gamma$ ) release assays (IGRA) [2,9-11]. The TST measures the delayed-type hypersensitivity response to intradermal injection of purified protein derivative, a crude mixture of several mycobacterial antigens which are common to M. tuberculosis, M. bovis BCG, and non-tuberculous mycobacteria (NTM) [10]. In turn, IGRA is an in vitro blood test, detecting the release of IFN- $\gamma$ by circulating T-lymphocytes in response to epitopes from specific $M$. tuberculosis complex-associated antigens, namely ESAT- 6 and CFP-10 $[2,11]$. The TST is a simple and cost-effective test, but it needs a follow-up visit for result interpretation $[10,11]$, while IGRA requires blood samples and a laboratory to process them quickly after collection [11].

There is a body of research on comparing the performance of TST and IGRA in the general population [12] and in specific population subgroups such as children, immunocompromised people, those from countries with high TB rates [13], contacts of active TB cases [4, $14,15]$, homeless people, refugees, HIV-positive cases [16], and HCW [14, 17-22]. There are no consistent results across studies and such variability could be explained by differences in demographic characteristics $[16,20]$, the community TB burden $[4,13]$, the immune status [13], or the prevalence of the BCG vaccination $[16,20]$. 
Table 1. Predictors of positive IGRA or positive TST

\begin{tabular}{|c|c|c|c|c|c|c|}
\hline & & Total & Positive TST & $\mathrm{OR}^{1}(95 \% \mathrm{CI})$ & Positive IGRA & $\mathrm{OR}^{2}(95 \% \mathrm{CI})$ \\
\hline Age, years & & $43.8 \pm 15.94$ & $\begin{array}{l}44.6 \pm 15.25 \\
p=\mathbf{0 . 1 7 4}\end{array}$ & $1.03(1.00-1.05)$ & $\begin{array}{l}46.8 \pm 16.16 \\
p=\mathbf{0 . 0 0 1}\end{array}$ & $1.02(1.00-1.03)$ \\
\hline Gender & $\begin{array}{l}\text { Female } \\
\text { Male }\end{array}$ & $\begin{array}{l}183 \\
184\end{array}$ & $\begin{array}{l}146(79.8) \\
147(79.9) \\
p=\mathbf{0 . 9 7 9}\end{array}$ & $\begin{array}{l}1 \\
0.78(0.42-1.47)\end{array}$ & $\begin{array}{l}78(42.6) \\
91(49.5) \\
p=\mathbf{0 . 2 2 7}\end{array}$ & $\begin{array}{l}1 \\
0.80(0.47-1.36)\end{array}$ \\
\hline HIV status & $\begin{array}{l}\text { Negative } \\
\text { Positive } \\
\text { Unknown }\end{array}$ & $\begin{array}{r}298 \\
5 \\
64\end{array}$ & $\begin{array}{l}241(80.9) \\
4(80.0) \\
48(75.0) \\
p=\mathbf{0 . 9 6 1}\end{array}$ & $\begin{array}{l}1 \\
0.32(0.02-4.54)\end{array}$ & $\begin{array}{l}144(48.3) \\
3(60.0) \\
22(34.4) \\
p=\mathbf{0 . 9 4 7}\end{array}$ & $\begin{array}{l}1 \\
0.56(0.07-4.57)\end{array}$ \\
\hline
\end{tabular}

Data are presented as the mean $\pm \mathrm{SD}$ or $n(\%)$. $p$ corresponds to the $p$ value for bivariate analysis comparing positive and negative results. TB, tuberculosis; HCW, healthcare workers.

${ }^{1}$ Adjusted for all other variables in the table; Hosmer-Lemeshow goodness-of-fit test $p$ value $=0.416$.

${ }^{2}$ Adjusted for all other variables in the table; Hosmer-Lemeshow goodness-of-fit test $p$ value $=0.809$.

Although the TB incidence rate in Portugal has been decreasing, it remains one of the highest $\mathrm{TB}$ rates in $\mathrm{Eu}-$ rope [23], demanding effective identification and treatment of individuals with LTBI. As far as we know, the performance of TST and IGRA for diagnosing LTBI in the Portuguese population was limited to the screen of HCW $[21,22]$. Thus, we aimed to determine the proportion of LTBI by using the TST and the IGRA test and to assess the risk factors related with discordant results between tests across several risk groups advised for screening in Northeast Portugal.

\section{Materials and Methods}

This study was carried out in a public health unit in the Northeast Portugal. Data were collected from the database of patients with suspected LTBI and advised for screening. In our setting it is mandatory to fill in a questionnaire asking for relevant information before patients undergo screening tests for LTBI. The questionnaire asks for the following information: age, gender, BCG vaccination status, HIV/SIDA diagnosis, and the reason for the suspected LTBI. All 377 patients screened between January 2014 and December 2015 who underwent both TST and IGRA were considered eligible participants. After excluding $3(0.8 \%)$ patients with indeterminate IGRA and 7 (1.9\%) patients due to a diagnosis of active TB, 367 participants were included in the present analysis.

\section{TST and IGRA}

Blood was collected for the IGRA and analyzed with the QuantiFERON Gold In-Tube assay (Cellestis/Qiagen, Dusseldorf, Germany). The IGRA method quantifies the IFN- $\gamma$ released after the incubation of blood with a cocktail of peptides derived from ESAT6, CFP-10, and TB7.7 (Rv2654c) antigens [24]. The IGRA was considered positive if the level of IFN- $\gamma$ was $0.35 \mathrm{IU} / \mathrm{mL}$ or more [24].

The TST was performed by using an intradermal injection of $5 \mathrm{U}$ of tuberculin (Pasteur Institute, Paris, France) on the volar side of the forearm. The transverse diameter of induration was read $72 \mathrm{~h}$ later [25]. Following recent guidelines, the TST was considered positive if the diameter of induration had $5 \mathrm{~mm}$ or more among children aged less than 5 years old, immunocompromised people, and those with a diagnosis of HIV/SIDA [26].

\section{Potential Predictors}

The following variables were considered potential predictors of TST or IGRA positivity and were retrieved from the database: gender, age, BCG immunization, HIV status and risk group for TB 
Table 2. Risk of discordant TST+/IGRA- results

\begin{tabular}{|c|c|c|c|c|c|c|c|}
\hline & & $\begin{array}{l}\text { TST-/IGRA- } \\
(n=59)\end{array}$ & $\begin{array}{l}\text { TST }+/ \text { IGRA }+ \\
(n=154)\end{array}$ & $\begin{array}{l}\text { TST-/IGRA+ } \\
(n=15)\end{array}$ & $\begin{array}{l}\text { TST+/IGRA- } \\
(n=139)\end{array}$ & $p$ value $^{1}$ & $\begin{array}{l}\text { Adjusted OR } \\
(95 \% \mathrm{CI}) \\
\text { discordant vs. } \\
\text { concordant }\end{array}$ \\
\hline Age, years & & $40.4 \pm 17.91$ & $44.7 \pm 15.77$ & $42.2 \pm 19.65$ & $41.6 \pm 14.13$ & 0.009 & $1.00(0.98-1.01)$ \\
\hline \multirow[t]{2}{*}{ Gender } & Female & $32(17.5)$ & $73(39.9)$ & $5(2.7)$ & $73(39.9)$ & \multirow[t]{2}{*}{0.414} & 1 \\
\hline & Male & $27(14.7)$ & $81(44.0)$ & $10(5.4)$ & $66(35.9)$ & & $1.31(0.77-2.21$ \\
\hline \multirow{2}{*}{$\begin{array}{l}\text { BCG } \\
\text { immunization }\end{array}$} & No & $7(16.3)$ & $21(48.8)$ & $4(9.3)$ & $11(25.6)$ & \multirow[t]{2}{*}{0.019} & 1 \\
\hline & Yes & $29(19.1)$ & $44(28.9)$ & $6(3.9)$ & $73(48.0)$ & & $1.77(0.80-3.93)$ \\
\hline \multirow[t]{2}{*}{ HIV status } & Negative & $43(14.4)$ & $130(43.6)$ & $14(5.0)$ & $111(36.6)$ & \multirow[t]{2}{*}{0.792} & 1 \\
\hline & Positive & $1(20.0)$ & $3(60.0)$ & $0(0.0)$ & $1(20.0)$ & & $0.55(0.06-5.57)$ \\
\hline \multirow{5}{*}{$\begin{array}{l}\text { Risk groups } \\
\text { for TB }\end{array}$} & Contacts of active TB cases & $27(17.2)$ & $75(47.8)$ & $8(5.1)$ & $47(29.9)$ & \multirow[t]{5}{*}{$<0.001$} & 1 \\
\hline & $\mathrm{HCW}$ & $5(5.8)$ & $29(33.7)$ & $0(0.0)$ & $52(60.5)$ & & $3.34(1.84-6.05)$ \\
\hline & Inmates & $2(3.4)$ & $33(56.9)$ & $2(3.4)$ & $21(36.2)$ & & $1.39(0.68-2.84)$ \\
\hline & Immunodepression & $19(51.4)$ & $7(18.9)$ & $3(8.1)$ & $8(21.6)$ & & $0.89(0.39-2.03)$ \\
\hline & Other & $6(20.7)$ & $10(34.5)$ & $2(6.9)$ & $11(37.9)$ & & $1.53(0.67-3.52)$ \\
\hline
\end{tabular}

(contacts of active TB, HCW, inmates, immunodepression status, and other circumstances).

\section{Statistical Analysis}

Participants were classified as LTBI positive or LTBI negative for each test (TST and IGRA) and were categorized into four groups: negative for both tests (TST-/IGRA-), positive for both tests (TST+/IGRA+), discordant with positive TST (TST+/IGRA-), and discordant with positive IGRA (TST-/IGRA+). The proportion of positive TST ( $\geq 5 \mathrm{~mm}$ for children aged less than 5 years, immunocompromised people, and those with a diagnosis of HIV/ SIDA or $\geq 10 \mathrm{~mm}$ for other people) or positive IGRA ( $\geq 0.35 \mathrm{IU} /$ $\mathrm{mL}$ ), concordant positive, concordant negative, and discordant tests were computed. Bivariate analysis was performed to compare groups according to the TST and IGRA results. Multivariate logistic regression analysis was performed to evaluate the association between a positive TST, a positive IGRA, or a discordant result as dependent variables, and the age, gender, HIV status, BCG immunization status, and the risk group of the patients as potential predictors of LTBI proportion. Estimates of odds ratio (OR) adjusted for all these potential predictors and the respective 95\% confidence interval (95\% CI) were obtained. Analyses were performed using the SPSS statistical software for Windows (SPSS version 26.0). The general significance level was set to 0.05 .

\section{Results}

A total of 367 individuals were included in this analysis; $42.7 \%(n=157)$ were contacts of active TB cases, $23.4 \%(n=86)$ were $\mathrm{HCW}, 15.8 \%(n=58)$ were inmates,
$10.1 \%(n=37)$ were immunosuppressed people, and $7.9 \%$ $(n=29)$ corresponded to other risk groups. Out of all of the participants, $79.8 \%(n=293)$ had a positive TST and $46.0 \%(n=169)$ of them had a positive IGRA.

Table 1 presents the proportion of positive TST or positive IGRA. According to the bivariate analysis, the proportion of positive TST was significantly different across risk groups for TB $(p<0.001)$, varying from $40.5 \%$ (immunocompromised people) to $94.2 \%$ (HCW). The proportion of IGRA positivity was significantly different between groups by BCG immunization ( $p=$ 0.005 ), varying from $32.9 \%$ (vaccinated) to $58.1 \%$ (nonvaccinated), and across risk groups for TB $(p=0.001)$, varying between $27.0 \%$ (immunocompromised people) and $60.3 \%$ (inmates). After adjustment for all other variables, older people were more likely to present TST positivity (OR 1.03, 95\% CI 1.01-1.05) or IGRA positivity (OR 1.02, 95\% CI 1.00-1.03). Compared with TB contacts, the odds of TST positivity was higher among HCW and inmates (OR 4.38, 95\% CI 1.59-12.09 and OR 4.74, 95\% CI 1.45-15.49, respectively) but lower among immunocompromised subjects (OR 0.14, 95\% CI 0.06-0.31). The odds of IGRA positivity were lower among BCG-vaccinated people (OR 0.34, 95\% CI 0.150.76) compared with non-vaccinated people. When compared with TB contacts, HCW and immunocompromised people presented lower odds of a positive 
IGRA (OR 0.44, 95\% CI 0.24-0.80 and OR 0.24, 95\% CI $0.10-0.56$, respectively).

Table 2 shows the proportion of discordant and concordant results by groups according to the potential predictors. There were $42.0 \%(n=154)$ TST+/IGRA+, $16.1 \%$ $(n=59)$ TST-/IGRA-, 4.1\% $(n=15)$ TST-/IGRA + , and $37.9 \%(n=139)$ TST+/IGRA-. According to the bivariate analysis, some variables presented a significant association with discordant results, namely age $(p=0.009)$, BCG immunization $(p=0.019)$, and the risk groups for TB $(p<0.001)$. However, after adjustment for all other variables, only risk groups for TB were related with a discordant result; compared with TB contacts, HCW had 3-fold higher odds of a discordant result (OR 3.34, 95\% CI 1.846.05).

\section{Discussion}

This is the first study conducted in Northeast Portugal on the proportion of LTBI, for which purpose we used TST and IGRA. According to our results, the proportion of LTBI estimated by IGRA and TST was 46 and 80\%, respectively. Among HCW, the proportion of positive IGRA was $34 \%$, similar to data reported in previous research conducted in Portugal [21]. However, according to a recent systematic review, the prevalence of LTBI among HCW by using IGRA in low-incidence countries was only $16 \%$ [27]. Also, the proportion of LTBI we found among $\mathrm{TB}$ contacts and inmates was higher than reported in other European settings [4, 14, 28, 29]. Our findings probably reflect the TB burden in Portugal, a country with one of the highest incidence rates $(20.5$ new cases and relapses of TB per 100,000 population) and with one of the lowest TB treatment success rates (37.3\%) among European countries in 2018 [23].

Previous research has reported the association between positive results with TST or IGRA and several predictors of TB $[5,12,15,17-20]$, but there are no consistent results across studies. We found an association between age and positive results with both tests, with older people presenting a higher risk of a positive test, in accordance with some previous studies [12, 15]. However, in other studies, age was related only with IGRA results [14, 18 ] or no association existed between age and positivity, either with TST or IGRA $[5,19,20]$.

We found no association between BCG immunization and TST positivity. Interestingly, IGRA positivity was less likely among immunized people, in accordance with previous research suggesting the relevance of the IGRA

TST versus IGRA among Users of a Public Health Unit in Northeast Portugal screening test in LTBI evaluation [12, 19]. The higher specificity of IGRA to detect $M$. tuberculosis infection [29] and the protective effect of BCG vaccination on $M$. tuberculosis infection [12] could explain our results.

Despite the lack of a gold standard to diagnose LTBI, we compared IGRA with TST results for estimate the proportion of LTBI among people with suspected LTBI and advised for screening. Our findings showed a low rate of TST-/IGRA- (16.1\%), while the rate of TST+/IGRA+ reached $42.0 \%$. Previous research enrolling TB contacts and $\mathrm{HCW}[14,17,19]$ reported a lower rate of TST+/ IGRA + and higher rate of TST-/IGRA - than we found. In some settings the diagnosis of LTBI is only considered when both tests are positive [3]; therefore, our results suggest a high risk of LTBI among people advised for the screening in our setting, demanding preventive strategies against TB.

The proportion of LTBI we found was higher when using TST than when using IGRA, which leads to a higher proportion of TST+/IGRA - among discordant results, and these findings are in accordance with previous research $[14,17,19,20]$. However, our rate of discordant results $(41.9 \%)$ was higher, particularly among HCW (61\%), than reported in previous research $[14,17,19]$. According to our results, in comparison with TB contacts, HCW presented a higher proportion of TST positivity but lower proportion of IGRA positivity. It has been reported that IGRAs provide higher specificity than the TST [30]. The TST is more sensitive than IGRA $[2,11,30]$ as a positive TST may be due to BCG vaccination or exposure to environmental NTM $[2,11]$. According to our results, BCG vaccination did not explain discordant results after adjusting for the other variables, indicating the impact of other factors, rather than BCG vaccination, in explaining discordant results. Indeed, only HCW remains a predictor of discordant results, and the discordant results in this group are TST+/IGRA-. Repeated TST as a surveillance strategy among HCW could boost the TST reaction among those with a previous $M$. tuberculosis or NTM infection [31,32], similar to what has been observed among BCG-vaccinated people [32]. It is not clear whether these results could be explained by the exposure to NTM [2], as NTM infections appear responsible for positive TSTs among HCW [31].

Based on WHO recommendations, either TST or IGRA can be used to evaluated LTBI, because no strong evidence suggests that one test should be preferred over the other for predicting progression to active TB disease [8]. However, the TST and IGRA results we observed across risk groups suggest the need for caution in reading 
the TST, as it seems be affected by other factors rather than recent exposure to M. tuberculosis.

The current study gives insights concerning the proportion of LTBI in several risk groups for TB by including all individuals with suspected LTBI in a specific community in Northeast Portugal who were advised for the screening. Nevertheless, there are some limitations. As we used the data from a single public health unit, we should be cautious in generalizing the findings. Furthermore, we missed some details. We have no information about the number of years in the healthcare profession, level of occupational risk or job category, and the time of exposure to $M$. tuberculosis, which have been reported to be associated with LTBI $[4,17,33]$.

\section{Conclusion}

The proportion of LTBI estimated by TST and IGRA is high among people advised for LTBI screening in Northeast Portugal, highlighting the need for strategies to control TB. The interpretation of TST results requires caution, particularly among HCW, due to a higher proportion of TST+/IGRA-, suggesting the impact of the booster reaction to previous $M$. tuberculosis exposure. Further research is needed by including more detailed information about participants.

\section{Acknowledgements}

The authors thank the Unidade Local de Saúde do Nordeste for allowing access to the data.

\section{Statement of Ethics}

The authors declare that they complied with ethics guidelines. The study protocol was approved by the Ethical Committe of the Unidade Local de Saúde do Nordeste (No. 28/2020).

\section{Conflict of Interest Statement}

The authors declare that they have no conflicts of interest.

\section{Funding Sources}

There were no funding sources for this research.

\section{Author Contributions}

A.L.F.A. conceived this study and collaborated in the data collection; B.M.M.P. collected the data; C.M.T. carried out the statistical analysis of the data. A.J.N. supervised all aspects of this work. All of the authors contributed to the interpretation of the results, writing the article, and proof reading of the manuscript.

\section{References}

1 World Health Organization. Global tuberculosis report. Geneva: WHO; 2019 [cited 2020 July-4]. Available from: https://www.who.int/ tb/publications/global_report/en/.

2 Sia JK, Rengarajan J. Immunology of Mycobacterium tuberculosis infections. Microbiol Spectr. 2019;7(4):10.

3 Mandal P, Craxton R, Chalmers JD, Gilhooley S, Laurenson IF, McSparron C, et al. Contact tracing in pulmonary and non-pulmonary tuberculosis. QJM. 2012 Aug;105(8):741-7.

4 Altet N, Dominguez J, Souza-Galvão ML, Jiménez-Fuentes MÁ, Milà C, Solsona J, et al. Predicting the development of tuberculosis with the tuberculin skin test and QuantiFERON testing. Ann Am Thorac Soc. 2015 May; 12(5):680-8.

5 Herzmann C, Sotgiu G, Bellinger O, Diel R, Gerdes S, Goetsch U, et al.; TB or not TB consortium. Risk for latent and active tuberculosis in Germany. Infection. 2017 Jun;45(3): 283-90.

6 Narasimhan P, Wood J, Macintyre CR, Mathai D. Risk factors for tuberculosis. Pulm Med. 2013;2013:828939.
7 Baussano I, Nunn P, Williams B, Pivetta E, Bugiani M, Scano F. Tuberculosis among health care workers. Emerg Infect Dis. 2011 Mar;17(3):488-94.

8 World Health Organization. Latent tuberculosis infection: updated and consolidated guidelines for programmatic management. Geneva: WHO; 2018 [cited 2020 July-4]. Available from: https://www.who.int/tb/publications/2018/latent-tuberculosis-infection/ en/.

9 Nóbrega CC, Duarte R, Afonso AF, Ferreira CS, Roque S, Vasconcelos O, et al. A case-control study on the diagnostic potential of multiantigen serological tests for tuberculosis. Arch Clin Microbiol. 2012;3(2):1-4.

10 Gualano G, Mencarini P, Lauria FN, Palmieri F, Mfinanga S, Mwaba P, et al. Tuberculin skin test - outdated or still useful for Latent TB infection screening? Int J Infect Dis. 2019 Mar;80S:S20-2.

11 Pai M, Sotgiu G. Diagnostics for latent TB infection: incremental, not transformative progress. Eur Respir J. 2016 Mar;47(3):704-6.
12 Chen C, Zhu T, Wang Z, Peng H, Kong W, Zhou Y, et al. High Latent TB Infection rate and associated risk factors in the Eastern China of low TB incidence. PLoS One. 2015 Oct; 10(10):e0141511.

13 Auguste P, Tsertsvadze A, Pink J, Court R, McCarthy N, Sutcliffe P, et al. Comparing interferon-gamma release assays with tuberculin skin test for identifying latent tuberculosis infection that progresses to active tuberculosis: systematic review and metaanalysis. BMC Infect Dis. 2017 Mar; 17(1): 200.

14 Nienhaus A, Schablon A, Diel R. Interferongamma release assay for the diagnosis of latent TB infection-analysis of discordant results, when compared to the tuberculin skin test. PLoS One. 2008 Jul;3(7):e2665.

15 Shanaube K, Hargreaves J, Fielding K, Schaap A, Lawrence KA, Hensen B, et al. Risk factors associated with positive QuantiFERON-TB Gold In-Tube and tuberculin skin tests results in Zambia and South Africa. PLoS One. 2011 Apr;6(4):e18206. 
16 Weinfurter P, Blumberg HM, Goldbaum G, Royce R, Pang J, Tapia J, et al.; Tuberculosis Epidemiological Studies Consortium. Predictors of discordant tuberculin skin test and QuantiFERON $^{\circledR}$-TB Gold In-Tube results in various high-risk groups. Int J Tuberc Lung Dis. 2011 Aug;15(8):1056-61.

17 Al Hajoj S, Varghese B, Datijan A, Shoukri M, Alzahrani A, Alkhenizan A, et al. Interferon Gamma Release Assay versus Tuberculin Skin Testing among healthcare workers of highly diverse origin in a moderate tuberculosis burden country. PLoS One. 2016 May; 11(5): $\mathrm{e} 0154803$.

18 Hung WT, Lee SS, Sy CL, Wu KS, Chen JK, Tsai HC, et al. Prevalence of latent tuberculosis infection in BCG-vaccinated healthcare workers by using an interferon-gamma release assay and the tuberculin skin test in an intermediate tuberculosis burden country. J Microbiol Immunol Infect. 2015 Apr;48(2): 147-52.

19 de Souza FM, do Prado TN, Pinheiro JS, Peres RL, Lacerda TC, Loureiro RB, et al. Comparison of interferon- $\gamma$ release assay to two cut-off points of tuberculin skin test to detect latent Mycobacterium tuberculosis infection in primary health care workers. PLoS One. 2014 Aug;9(8):e102773.

20 Gran G, Aßmus J, Dyrhol-Riise AM. Screening for latent tuberculosis in Norwegian health care workers: high frequency of discordant tuberculin skin test positive and interferon-gamma release assay negative results. BMC Public Health. 2013 Apr;13(1):353.

21 Torres Costa J, Silva R, Sá R, Cardoso MJ, Nienhaus A. Results of five-year systematic screening for latent tuberculosis infection in healthcare workers in Portugal. J Occup Med Toxicol. 2010 Jul;5(1):22.
22 Shapovalova O, Sacadura Leite E, Galaio LM, Pereira I, Rocha R, Sousa Uva A. Tuberculose latente em profissionais de saúde: concordância entre 2 testes diagnósticos. Rev Port Saude Publica. 2016;34(1):3-10.

23 European Centre for Disease Prevention and Control. Tuberculosis surveillance and monitoring in Europe 2020-2018 data. Stockholm: ECDC; 2020 [cited 2020 Sept-1]. Available from: https://www.ecdc.europa.eu/en/publications-data/tuberculosis-surveillance-andmonitoring-europe-2020-2018-data.

24 Carrère-Kremer S, Rubbo PA, Pisoni A, Bendriss S, Marin G, Peries M, et al. High IFN- $\gamma$ release and impaired capacity of multi-cytokine secretion in IGRA supernatants are associated with active tuberculosis. PLoS One. 2016 Sep;11(9):e0162137.

25 Duarte R, Amado J, Lucas H, Sapage JM; Portuguese Society of Pulmonology. [Treatment of latent tuberculosis infection: update of guidelines, 2006]. Rev Port Pneumol. 2007 May-Jun;13(3):397-418.

26 Lewinsohn DM, Leonard MK, LoBue PA, Cohn DL, Daley CL, Desmond E, et al. Official American Thoracic Society/Infectious Diseases Society of America/Centers for Disease Control and Prevention clinical practice guidelines: diagnosis of tuberculosis in adults and children. Clin Infect Dis. 2017 Jan; 64(2):e1-33.

27 Peters C, Kozak A, Nienhaus A, Schablon A. Risk of occupational latent tuberculosis infection among health personnel measured by interferon-gamma release assays in low incidence countries: a systematic review and meta-analysis. Int J Environ Res Public Health. $2020 \mathrm{Jan} ; 17(2): 581$
28 Godoy P, Caylà JA, Carmona G, Camps N, Álvarez J, Alsedà M, et al.; Grupo de Trabajo de Estudios de Contactos de Tuberculosis de Cataluña. Smoking in tuberculosis patients increases the risk of infection in their contacts. Int J Tuberc Lung Dis. 2013 Jun; 17(6): 771-6.

29 Marco Mouriño A, Orcau Palau A, Jané Galliga $R$, Escribano Ibáñez $M$, Caylà Buqueras JA, Solé Zapata N, et al. [Concordance of tuberculin tests and Interferon gamma release assays in the prison population]. Rev Esp Sanid Penit. 2011;13(1):15-20.

30 Doan TN, Eisen DP, Rose MT, Slack A, Stearnes G, McBryde ES. Interferon-gamma release assay for the diagnosis of latent tuberculosis infection: A latent-class analysis. PLoS One. 2017 Nov;12(11):e0188631.

31 von Reyn CF, Horsburgh CR, Olivier KN, Barnes PF, Waddell R, Warren C, et al. Skin test reactions to Mycobacterium tuberculosis purified protein derivative and Mycobacterium avium sensitin among health care workers and medical students in the United States. Int J Tuberc Lung Dis. 2001 Dec;5(12):11228.

32 Farah WH, Breeher LE, Newcomb RD, Murad MH, Vaughn AI, Hagen PT, et al. Late boosting phenomenon in TST conversion among health care workers. Occup Med. 2017 Aug;67(6):484-9.

33 El-Helaly M, Khan W, El-Saed A, Balkhy HH. Pre-employment screening of latent tuberculosis infection among healthcare workers using tuberculin skin test and QuantiFERONTB Gold test at a tertiary care hospital in Saudi Arabia. J Infect Public Health. 2014 Nov-Dec;7(6):481-8. 